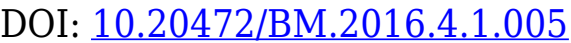

\title{
DOES THE COUNTRY OF ORIGIN MATTERS FOR HYBRID PRODUCTS?
}

\section{ANCA TAMAS}

\section{Abstract:}

Purpose-the aim of the paper is to assess how is Country of origin perceived for the hybrid products by the Romanian consumers.

Design/methodology/approach-statistical analyze and econometric methods, using SPSS, the Pearson correlation, the cluster method, the t-test; critical assessment of literature review; quantitative methods: 126 online questionnaires.

Findings-Country of origin is important for buying decision in the case of hybrid products; Country of Brand is mostly perceived as the Country of Origin of the considered hybrid products; identifying the Country of Origin is more demanding for hybrid products.

Practical implications-considering the consumers' opinions on the Country of Origin for the hybrid products retailers could emphasize the Country of Brand.

Originality/value-providing an insight of an area with only few researches and an insight on the Romanian consumers.

Limitations-the respondents were only from the South part of Romania

\section{Keywords:}

country of origin, hybrid products

JEL Classification: D12, M31

\section{Authors:}

ANCA TAMAS, Bucharest University of Economic Studies, Romania, Email: ancuta_new@yahoo.com

\section{Citation:}

ANCA TAMAS (2016). Does the Country of Origin matters for hybrid products?. International Journal of Business and Management, Vol. IV(1), pp. 85-104., 10.20472/BM.2016.4.1.005 


\section{INTRODUCTION}

Once upon a time, before the dawn of globalization things were simple, the products were designed and manufactured or assembled in the one country, using parts also manufactured in the same country and sold in other countries, labeled "made in...". So were the services, they were designed and delivered by companies from the one country to other countries. And most of the people think that Country of Origin-COO- is simply the country written after "made in...".

But then some companies relocate part of their production abroad, to lower the production costs and to increase their competiveness, therefore the products that were designed in one country, manufactured in other country and then sold in other countries were called bi-national products. That was a major problem for the producers, for the marketers, for the consumers and for the researchers in the same time. What should be written after the "Made in..." after all? Many of us can remember we had bought products labeled "Made in Country A" and "Designed in country B". Country B was a developed country we used to associate the product with and Country $A$ was a less developed country, the one where the production was relocated to. Those labels leads to an informational incongruence and according to Osgood and Tannenbaum (1955) the subsequent evaluation of a bi-national product tend to move toward a congruence. So we either trusted in the good reputation and image of Country B, hope the product's quality will be the same and decide to buy the product or we were negatively influenced by the poor image of country $A$ and decided not to buy the product. The sellers emphasized either Country B as the $\mathrm{COO}$ or display other information to diminish the effect of Country $A$, such are the price, the warranty, the intrinsic cues of the product. The researchers decomposed the $\mathrm{COO}$ concept in the $\mathrm{COB}=$ country of brand- meaning the country the consumers perceive the product to belong to- (Thakor and Kohli, 1996) or COD-country of design (Jaffe and Nebenzahl, 2001) and COM=country of manufacture (Insch and McBride, 1998).

In the era of globalization things got even more complicated for all the mentioned actors because a new kind of products appeared, the ones called multi-national products because they were designed in country 1 , produced by a brand located in country 2 , assembled in country 3 , using parts manufactured in country 4 and sold in other countries but these. International rules were introduced for the "made in..." labels and these rules solved the producer's problems. The researchers decomposed the COO in COM, COB, COD (as mentioned above) and COP=country of parts (Chao, 1993), COA=country of assembly (Insch and McBride, 1998). The COO effect became a multi-dimensional construct and different experimental research found that for certain product classes, for certain kind of consumers the COB effect for instance was greater than COM effect. The marketers emphasized one cue or another usually combined with other intrinsic or extrinsic cues and the consumers have to assign different weights to different pieces of 
information in order to get to a buying decision. These multi-national products are now called hybrid products. The hybrid products are everywhere now: the cars, TV sets, computers and computer tablets, the smart phones, electronics, cosmetics, cloths, food.

The story of $\mathrm{COO}$ of the services is pretty similar to the story of products. They moved from uni-national services to bi-national services to multi-national services, which are called now of course hybrid services. According to Veale and Challen (2010), the COO for hybrid service can be decomposed in $\mathrm{COB}=$ country of brand, the country were the service provider is perceived to belong to; $C S D=$ the country were the service is delivered; $\mathrm{CPI}=$ country of person image, actually the $\mathrm{COO}$ of the person who delivers the service; $\mathrm{CTI}=$ the country where the person delivering the service was trained in. Examples of hybrid services: banking and insurances services, tertiary education services, medical services, tourism and travelling services (mainly flight services).

So we now have hybrid products and hybrid services, what else is hybrid? The hybrid consumers for instance are the consumers that buy cheap at low-end brands on some purchase occasions and pay premium prices at high-end brands on other purchase occasions (Ehrmrooth and Gronroos, 2013). The hybrid subcultures of the immigrants (Meng, Nasco and Clark, 2007), hybrid research methodologies such is MergedMethod, balancing deep qualitative insights and detailed quantitative data, hybrid marketing (Gandolfo and Padelletti, 1999).

\section{LITERATURE REVIEW}

Since there is no definition widely accepted for $\mathrm{COO}$ several definitions might be considered to clarify the concept, in a chronological order:

- An aspect of perception by which the information affects the evaluation of the product ( Gurhan-Canli, 2000)

- The image of the country is constructed from the consumers' subjective perpective (Jaffe and Nebenzahl, 2001)

- The image of a country is related with the products made in the country (Hamin and Elliott, 2005)

- $\mathrm{COO}$ is a factor that creates a positive or a negative perception on a product (Ghazali,Othman, Yahya and Ibrahim, 2008)

- The image of the country is projected on the products made in the country (Jenes, 2009)

\section{COO before the hybrid products}

First study on COO effect on consumers evaluation is the one of Schooler's (1965). In the early years of $\mathrm{COO}$ research the studies focused on the concept of "made in..."(Darling 
and Kraft, 1977), (Banister and Saunders, 1978).The various relationships between COO and other cues was investigated by Parameswaran and Yaprak (1987) with the product familiarity; Zhang (1997) with the need for cognition; Johansson, Nebenzahl (1986), Thorelli, Lim, Ye (1989) and Wall, Liefeld, Heslop (1991) with the perceived risks; Reierson (1966) with the consumers' prejudice on national products; Ahmed and D'Astous (1993) with the product involvement.

The COO cue was compared with warranty and retail store image (Thorelli, Lim and Ye, 1989), price and quality (Elliot and Cameron, 1994), intrinsic cues (Liefield and Wall, 1991), the power distance (Insch and McBride, 2004), national stereotypes (Reierson, 1966), national pride (Botschen and Hemettsberger, 1998), the degree of consumers' education (Anderson and Cunningham, 1972), the level of consumers' income (D'Astous and Ahmed, 1995), animosity toward the COO (Klein, Ettenson and Morris, 1998), country's type of culture (Gurhan-Canli and Maheswaran, 2000), ethnocentrism (Shimp and Sharma, 1987), lifestyle patterns (Kucukemiroglu, 1999), the degree of economical development and political freedom (Crawford and Lamb, 1981), country image (Chasin and Jaffe, 1979), product's life cycle (Lampert and Jaffe, 1998), brand (Thakor and Lavack, 2003).

\section{COO after hybrid products}

The concepts associated with $\mathrm{COO}$ are $\mathrm{BO}=$ brand origin (Thakor and Lavack, 1996), $\mathrm{COBO}=$ culture of brand origin ( $\mathrm{Lim}$ and $\mathrm{O}^{\prime}$ Cass, 2001), $\mathrm{PCl}=$ product country image ( Kaynak, Kucukemiroglu and Hyder, 2000), MCl-made in country image, MCIP- the image of a made in country as the producer of a specific product, MCIOC- the image of the country associated with the product by consumers, regardless to the country where the product is actually produced (Nebenzahl, Jaffe and Lampert, 1997),

COM was considered of little importance for the products they just have bought for consumers from developed countries such are USA (Hugstad and Durr, 1986), Canada (Hester and Yuen, 1987), France (Usunier, 2002).Comparing the importance of COB and COM, COM was less important than COB (Ulgado and Lee, 1993) or at the best of the same importance (Eroglu and Machleit, 1989), (lyer and Kalita, 1997), yet for bi-national products COM is more important than brand name (Han and Terpstra, 1988). Similarly COD was more important than COA (Chao, 1993) or of the same importance (Ahmed and D'Astous, 1995). The importance of COD and COM for bi-national products was analyzed in 2006 by Hamzaoui and Merunka.

The interactions between COD, COA and price in consumer evaluations of a hybrid product made in newly industrialized countries (Chao, 1993) and a few years later COA, COP, COD were moderators of a hybrid product's evaluation (Chao, 2001). Other interactions between brand name and $\mathrm{COO}$ for hybrid products were investigated (Ettenson and Gaeth, 1991). An interesting comparison between uni-national and binational products was made by Han and Terpstra in 1988 and similar comparisons were 
made in 1990 by Light, Gazda and Brown and in 2000 by Kim and Pysarchik. Tan and Leong found the warranty strategies for hybrid products, while Ulgado and Lee focused in 1999 on the role of hybrid products in the global market.

\section{COO of services}

In 2001 Javalgi, Cutler and Winans in their literature review discovered only 19 studies in 20 years focused on $\mathrm{COO}$ effects on services, and found a similar pattern between $\mathrm{COO}$ and products and $\mathrm{COO}$ and services. An interesting comparison between $\mathrm{COO}$ for products and for services was made by Nicolescu (2011). The impact of COO for different services were studied, the retail service (Pecotich, Pressley and Roth, 1996), international tertiary education (Bourke, 2000), (Srikatanyoo and Gnoth, 2002), (Tamas, 2014); service quality from consumers'perspective (Veale and Challen, 2010).

The hybrid products I will considered in this paper are: smart phone, PC tablet. iPod and iPad.

\section{RESEARCH HYPOTHESIS:}

$\mathrm{H} 1$ : COO is important for the buying decision of the hybrid products considered

$\mathrm{H} 2$ : the perceived $\mathrm{COO}$ is confusing for the buyers of the hybrid products

H3: The correlation between the perceived $\mathrm{COO}$ and the perceived $\mathrm{COB}, \mathrm{COM}$, and COD are significant, positive and medium strong for the considered hybrid products

$\mathrm{H} 4$ : the $\mathrm{COO}$ for the considered hybrid products is different for the evaluation of the product and for the purchase intention

\section{METHODOLOGY:}

I used quantitative method- questionnaires, there were self-administrated, send and collected by email. I asked the students in year 3 at Bucharest University of Economic Studies to find some friends or relatives from their home town mainly who have bought a smart phone, a PC tablet, an iPod or an iPad, to send them the questionnaires, ask them to fill in and then to send the questionnaires back to me by email. The students received extra credits for their extra work. In this way I hoped I will have for my study respondents from many regions of the country, of different ages, occupations and incomes. I got 126 responses from all the southern part of the country which is usually the pool for our University's students. Therefore the sample was made of students, employees, entrepreneurs, retired people. In the questionnaires I used 7-points Likert scale. I used SPSS to analyze the data from responses 
Table 1: The respondents' profile

\begin{tabular}{|c|c|c|c|}
\hline & & No & $\%$ \\
\hline \multirow[t]{2}{*}{ gender } & feminine & 64 & 50.8 \\
\hline & masculine & 62 & 49.2 \\
\hline \multirow{7}{*}{ occupation } & students & 13 & 10.3 \\
\hline & University students & 50 & 39.6 \\
\hline & entrepreneurs & 6 & 4.7 \\
\hline & unemployed & 2 & 1.5 \\
\hline & Public employee & 26 & 20.6 \\
\hline & Private employee & 25 & 19.8 \\
\hline & retired & 4 & 3.1 \\
\hline \multirow{4}{*}{$\begin{array}{c}\text { Income } \\
\text { level }\end{array}$} & No income & 45 & 35.7 \\
\hline & Below average & 7 & 5.5 \\
\hline & average & 44 & 34.9 \\
\hline & Above average & 30 & 23.8 \\
\hline \multirow[t]{4}{*}{ Age } & Under 20 & 17 & 13.7 \\
\hline & Between 20 and 40 & 91 & 72 \\
\hline & Between 40 and 60 & 15 & 12 \\
\hline & Over 60 & 3 & 2.3 \\
\hline \multirow[t]{2}{*}{ location } & Bucharest & 58 & 46 \\
\hline & 16 counties & 68 & 54 \\
\hline
\end{tabular}




\begin{tabular}{|l|c|c|c|}
\hline \multirow{2}{*}{ The hybrid product } & Smart phone & 77 & 61.1 \\
\cline { 2 - 4 } & PC tablet & 36 & 28.5 \\
\cline { 2 - 4 } & IPod & 6 & 4.7 \\
\cline { 2 - 4 } & iPad & 7 & 5.5 \\
\hline \multirow{2}{*}{ When was the product bought } & A year ago & 56 & 44.4 \\
\cline { 2 - 4 } & 1-3 years ago & 57 & 45.2 \\
\cline { 2 - 4 } & 3-5 years ago & 11 & 8.7 \\
\cline { 2 - 4 } & More than 5 years ago & 2 & 1.5 \\
\cline { 2 - 4 } & & & 57 \\
\hline
\end{tabular}

Source: author's table

Price, quality, technical features, the number of facilities are product related features, fashionable and luxury status are features related to consumer's status, while brand and design are features related to the product's COO. Due to the way the evaluation was made ( 1 for the most important, .., 8 for the least important), the most important feature had the lowest sum of scores, while the least important one had the higher sum of scores.

Table2: the sums of scores and the average for the eight features

\begin{tabular}{|c|c|c|}
\hline & Sum of scores & Average \\
\hline the quality & 369 & 2.92 \\
\hline technical features & 404 & 3.2 \\
\hline the price & 418 & 3.31 \\
\hline it has many facilities & 501 & 3.97 \\
\hline made by a well known brand & 520 & 4.12 \\
\hline the design & 525 & 4.16 \\
\hline fashionable & 642 & 5.09 \\
\hline offers a luxury status & 694 & 5.5 \\
\hline
\end{tabular}

Source: author's table 
For the 126 consumers the quality comes first, followed by technical features, price and facilities, the status had the least importance the $\mathrm{COO}$ features come in between.

Question no 5 ask the respondents to fill in the COO, COB, COM, COD for the product they had bought if they know any of them, the respondents may also choose "do not know any of the countries" or " $\mathrm{COO}$ is not important". I wanted to find out how they connected $\mathrm{COO}, \mathrm{COB}, \mathrm{COM}$ and $\mathrm{COD}$ for a hybrid product, and how they decide which one is COO assuming the other three are known. I also wanted to find out if the respondents wrote the same country at "made in..." from question no 3 and "COO" from question no 5. Here are the results:

Table 3: COO perception for hybrid products

\begin{tabular}{|c|c|c|}
\hline & No & $\%$ \\
\hline COO is not important & 18 & 14.2 \\
\hline Do not know the COO & 20 & 15.8 \\
\hline Know at least one of the following: COO. COB,COM, COD & 88 & 69.8 \\
\hline Know at least one of COO and COB & 98 & 77.7 \\
\hline Consider COO=COB & 45 out of 98 & 45.9 \\
\hline Consider COO is not COB & 12 out of 98 & 12.2 \\
\hline Know COB yet do not know COO & 33 out of 98 & 33.6 \\
\hline Know COO yet do not know COB & 8 out of 98 & 8.1 \\
\hline Know at least one of COO and COM & 88 & 69.8 \\
\hline Consider COO=COM & 41 out of 88 & 46.5 \\
\hline Consider COO is not COM & 15 out of 88 & 17 \\
\hline Know COM yet do not know COO & 23 out of 88 & 26.1 \\
\hline Know COO yet do not know COM & 9 out of 88 & 10.2 \\
\hline Know at least one of COO and COD & 87 & 69 \\
\hline
\end{tabular}




\begin{tabular}{|c|c|c|}
\hline Consider COO=COD & 37 out of 87 & 43.6 \\
\hline Consider COO is not COD & 12 out of 87 & 13.7 \\
\hline Know COD yet do not know COO & 22 out of 87 & 25.2 \\
\hline Know COO yet do not know COD & 16 out of 87 & 18.3 \\
\hline Know at least one of COO, COM, COD & 101 & 80.1 \\
\hline Consider COO=COB=COM & 27 out of 101 & 26.7 \\
\hline Know at least one of COO and "Made in...."country & 83 & 65.8 \\
\hline Consider COO= “ made in..." country & 44 out of 83 & 69.1 \\
\hline Consider COO is not "made in..." country & 39 & 30.9 \\
\hline
\end{tabular}

Source: author's table

Figure 1: COO awarness

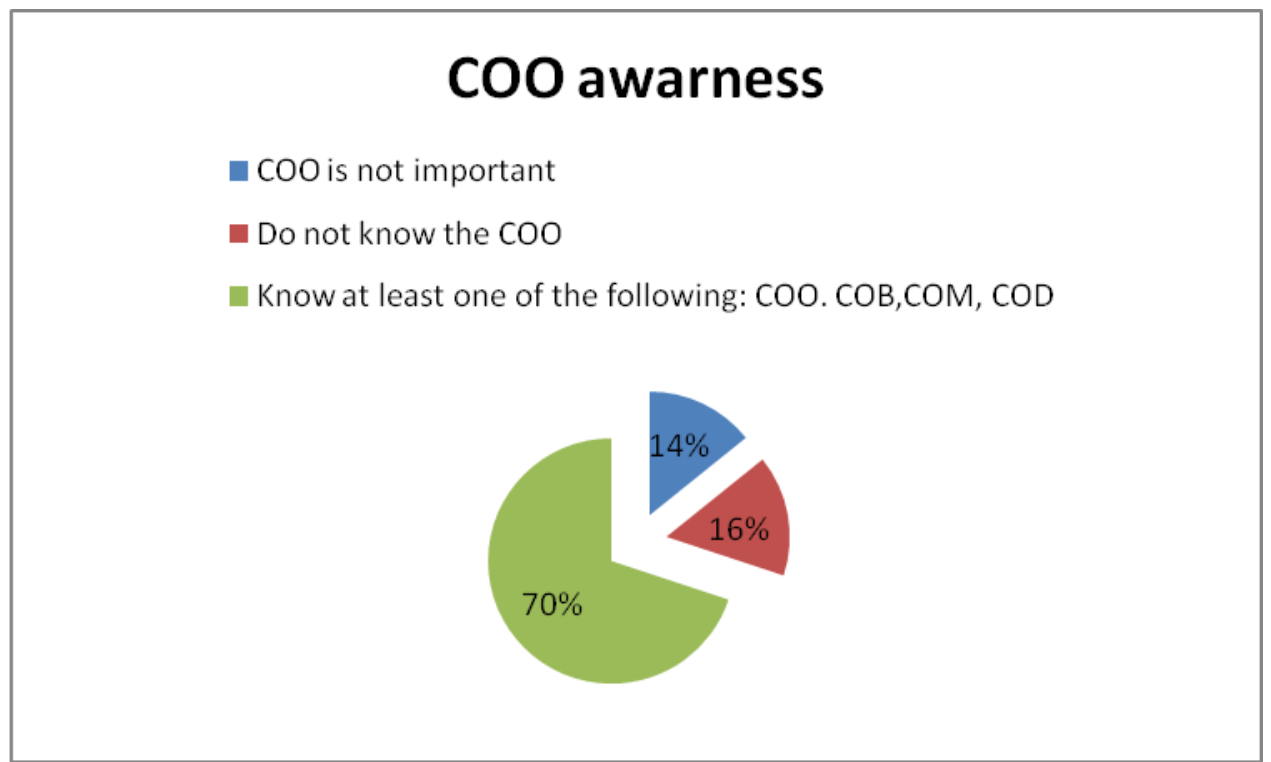

Source: chart based on the results in table 3

The respondents were asked to choose the statements they agree with, regarding their opinion toward the $\mathrm{COO}$ of the products they had bought. Each sentence refears to a variable related to $\mathrm{COO}$. 
S1:When I buy an expensive product I always try to find COM

EP:expensive product

S2: I think it is important to seek information on COO for a buying decision $\mathrm{COOl}=\mathrm{COO}$ info

S3: To make sure the product I buy is high quality I always check COM $\mathrm{COOQ}=$ check $\mathrm{COO}$ to evaluate quality

S4: If I am not familiar with the product I want to buy I seek info on COO for the buying decision

$\mathrm{NF}=$ not familiar

S5: I refuse to buy a product if I do not know its COO.

$\mathrm{R}=$ refuse to buy if $\mathrm{COO}$ is unknown

S6: When I buy a product I think COO determine the technological level of the product.

$\mathrm{COOT}=\mathrm{COO}$ determine the technological level

$\mathrm{S7}$ :When I buy a product COO is the major info I need.

$\mathrm{COOMI}=\mathrm{COO}$ is the major information

S8: COO of a product do not determine the quality of the product

$\mathrm{NCOOQ}=\mathrm{COO}$ do not determine the quality

S9: When a product has a hogh functional risk one should always check COO.

$\mathrm{FR}=$ functional risk

S10: When we buy a cheap product it is not so important to know COO.

$\mathrm{CP}=$ cheap product

S11: Finding information on $\mathrm{COO}$ is less important for cheap products comparing to expensive products.

$\mathrm{CEP}=$ cheap products versus expensive products

S12: I identify COO to determine the quality of the product.

$\mathrm{COOFQ}=$ identify $\mathrm{COO}$ to evaluate product

S13: When I buy a product for my family I seek information on $\mathrm{COO}$ of the product.

F=for family

S14: I seek information on COO to choose the best product from a class of products. 
$\mathrm{BP}=\mathrm{COO}$ information to choose the best product.

I applied the cluster analysis to see how are the variables grouping and I came to the following model. The results are consistent with the previous ones for the uni-national products:

- COO has a major influence on the price, and there is a strong direct relationship between the price and $\mathrm{COO}$.

- COO has a greater influence on evaluation of the products' quality comparing to the influence on the buying decision

- Technological level of the product and familiarity with the products are influenced by $\mathrm{COO}$

I used SPSS to find the Pearson correlations between COO. COB, COM and COD.

Table 4: Pearson correlation coefficient

\begin{tabular}{|c|c|c|c|c|}
\hline & COB & COM & COD & COO \\
\hline COB & 1 & 0.484 & 0.708 & 0.309 \\
\hline COM & 0.484 & 1 & 0.371 & 0.401 \\
\hline COD & 0.708 & 0.371 & 1 & 0.26 \\
\hline COO & 0.309 & 0.401 & 0.26 & 1 \\
\hline
\end{tabular}

Source: own table based on SPSS output

In table 4 we can see the Pearson correlation coefficients, they show that in the respondents' opinion there is a strong correlation between $\mathrm{COB}$ and $\mathrm{COD}$, medium correlations between $\mathrm{COB}$ and $\mathrm{COM}, \mathrm{COM}$ and $\mathrm{COO}, \mathrm{COM}$ and $\mathrm{COD}$ and low correlations between $\mathrm{COB}$ and $\mathrm{COO}$, between $\mathrm{COO}$ and $\mathrm{COD}$. I used the $t$ test to find out If $\mathrm{COO}$ is perceived to be $\mathrm{COB}, \mathrm{COM}, \mathrm{COD}$ or the "made in...." country and when compare $\mathrm{COO}$ and $\mathrm{COB}, \mathrm{p}$ was lower than 0.05 , therefore the null hypothesis should be accepted, and $\mathrm{COO}$ is perceived as $\mathrm{COB}$. In all the other cases $\mathrm{p}$ was greater than 0.05 , therefore COM, COD and "made in...." country are not perceived as COO. 
Figure 2: The cluster model
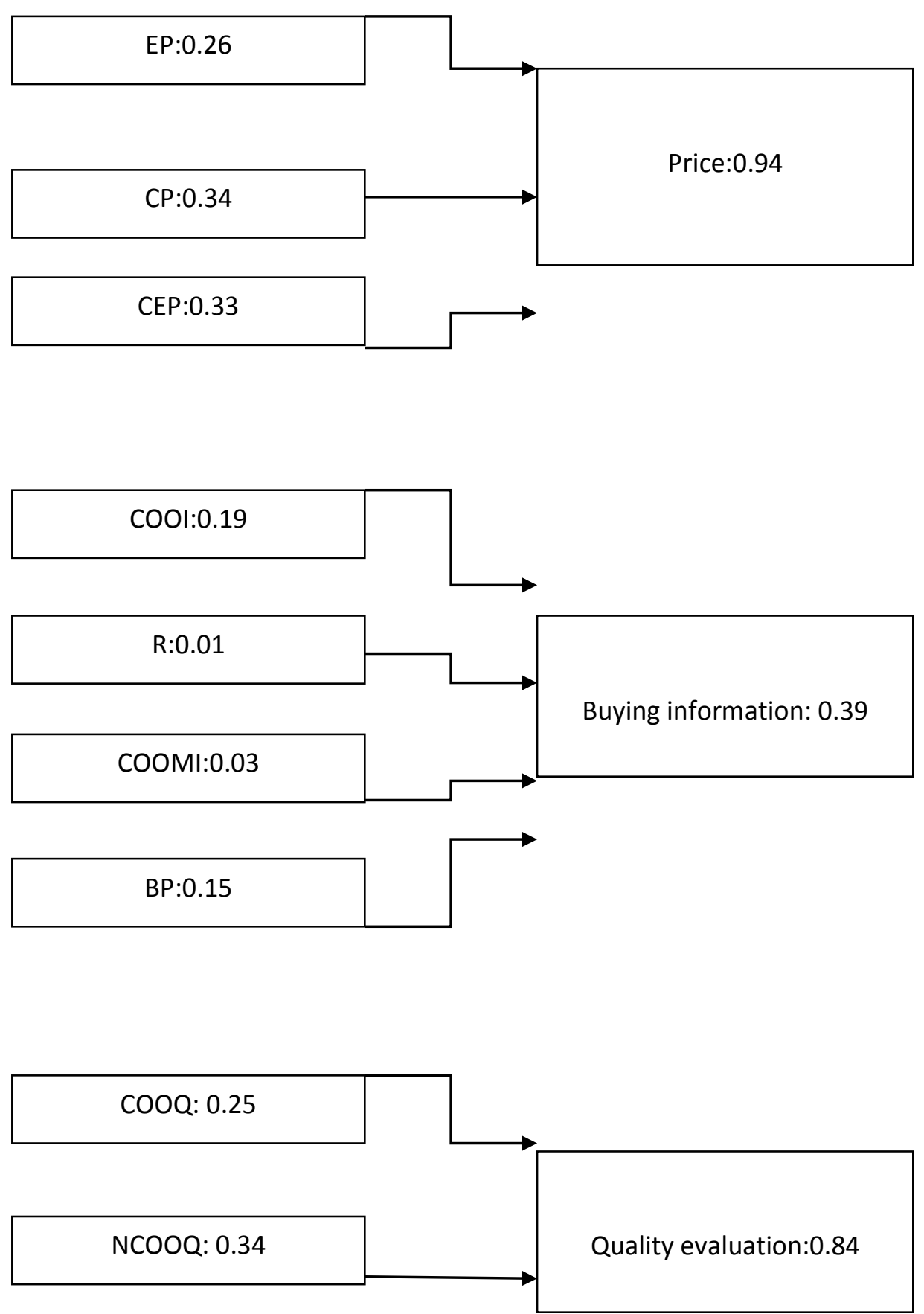

COOFQ: 0.25 

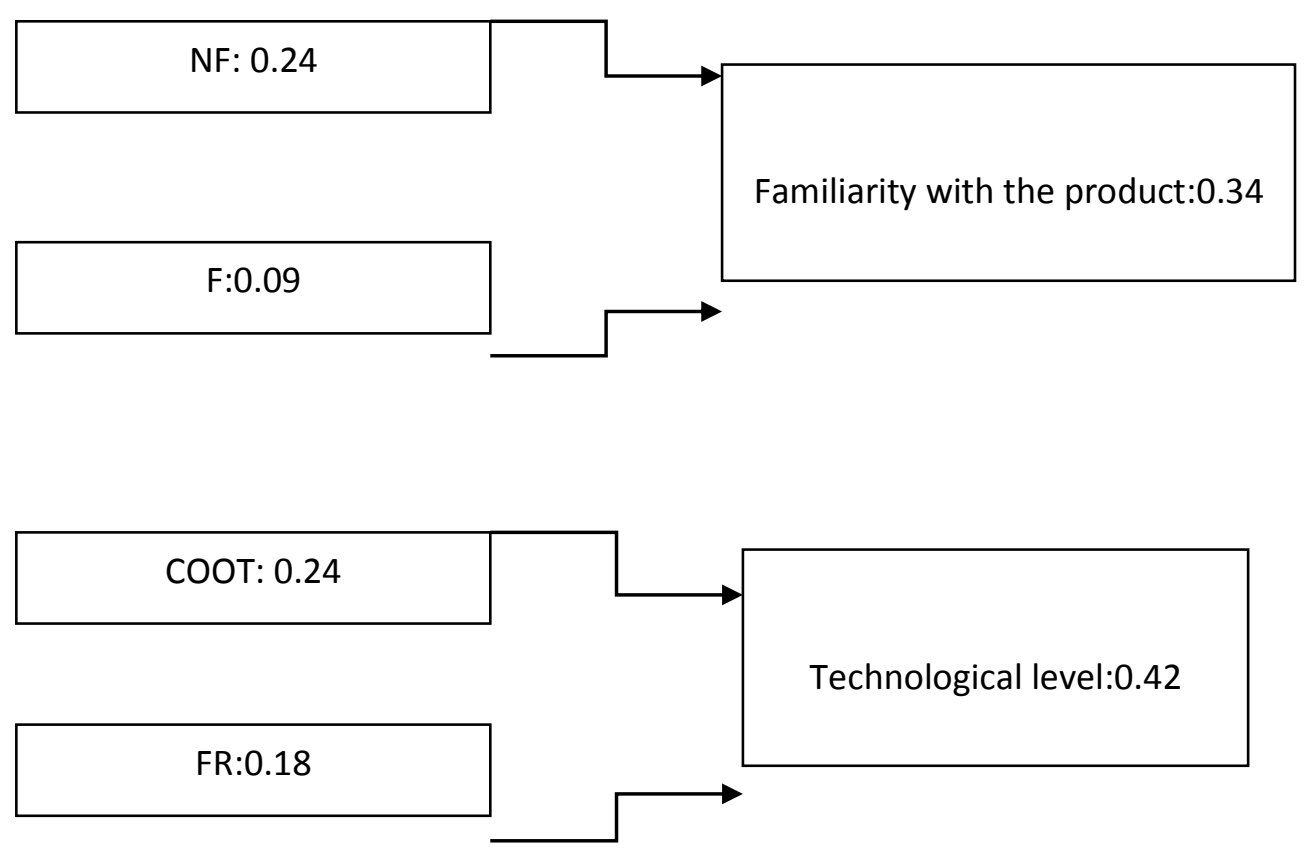

Source: own mode

I asked the respondents to imagine they will buy another hybrid product as smart phone, PC tablet, iPod, iPad and to fill in the most appropriate COO country of the above mentioned products related to the following products' features:
a. High quality
b. Very good workmanship
c. High tech
d. Special design
e. High status
f. High reputation
g. price
h. Many facilities
i. Great value

Finally I asked the respondents to fill in the following statements in order to assess their purchase intention

1. The COO for the smart phone/ PC tablet/ iPod/ iPad I would like should be. 
2. The COO of the next smart phone/ PC tablet/ iPod/ iPad I would by would be

3. If I would buy a smart phone/ PC tablet/ iPod/ iPad from unkown brand the COM would be.

Figure 3: the consumers' perception for the five leading countries

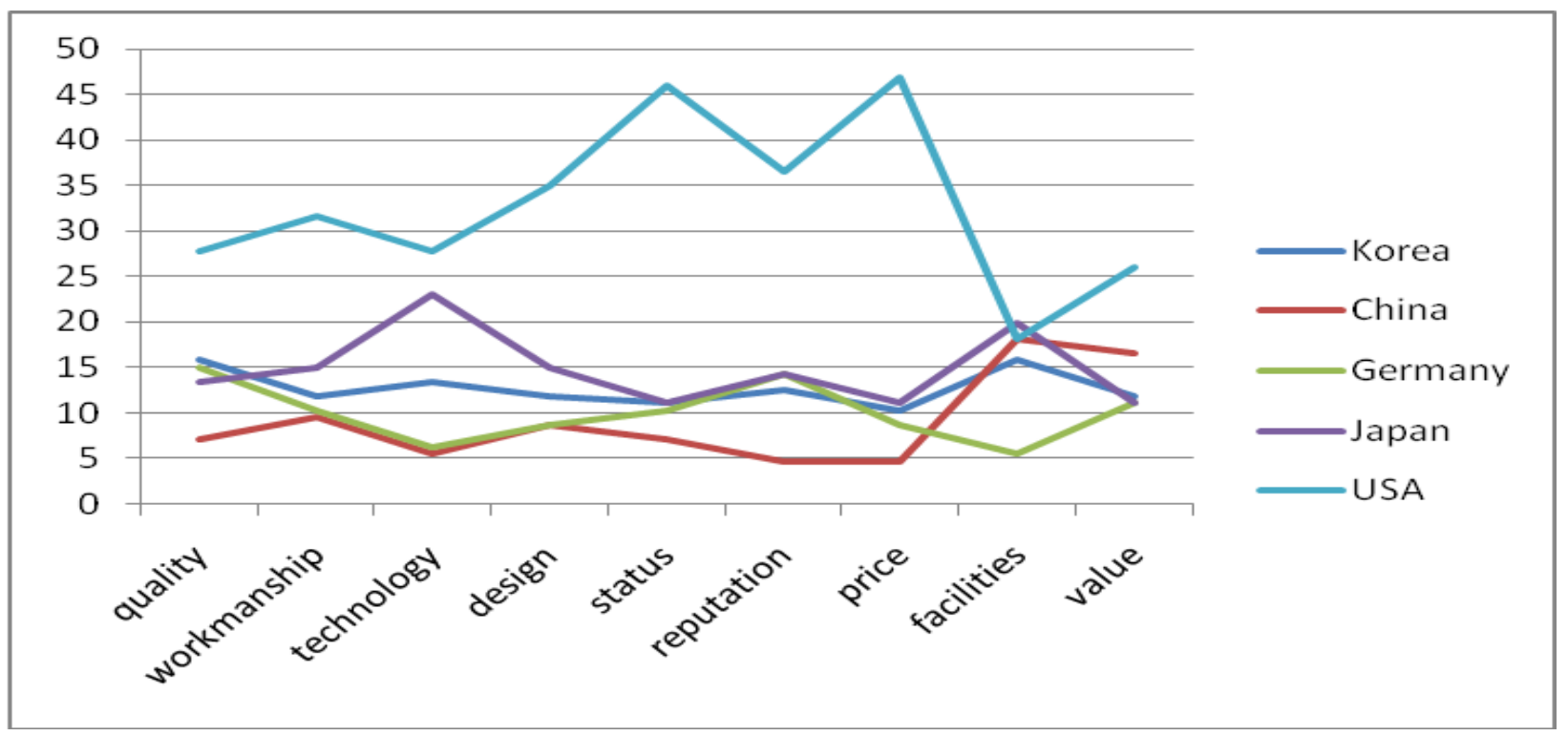

Source: own adaptation based on respondents' answers

These are the results:

- 20 countries were found at a least one of the product features, namely: Canada, China, Finland, France, Germany, Holland, Italy, Japan, Korea, Norway, Poland, Romania, Spain, Sweden, Switzerland, Taiwan, Thailand, UK, USA, Vietnam

- Among the 20 countries, only 5 got two digit scores at a least one feature, namely: China, Germany, Japan, Korea, USA

- Among the 20 countries only four countries are emerging countries, namely China, Romania, Poland, Thailand; all the other 16 countries are developed countries

- USA leads at all nine features, with Japan coming second for workmanship, technology, design, price and facilities, while Korea is on second place for quality and value; for reputation Japan and Korea shared the second place and

- China got the last place in all features but three, facilities and value where Germany got the last place, as for design China and Germany shared the last place. 
Figure 3: the consumers' purchase intention for the five leading countries

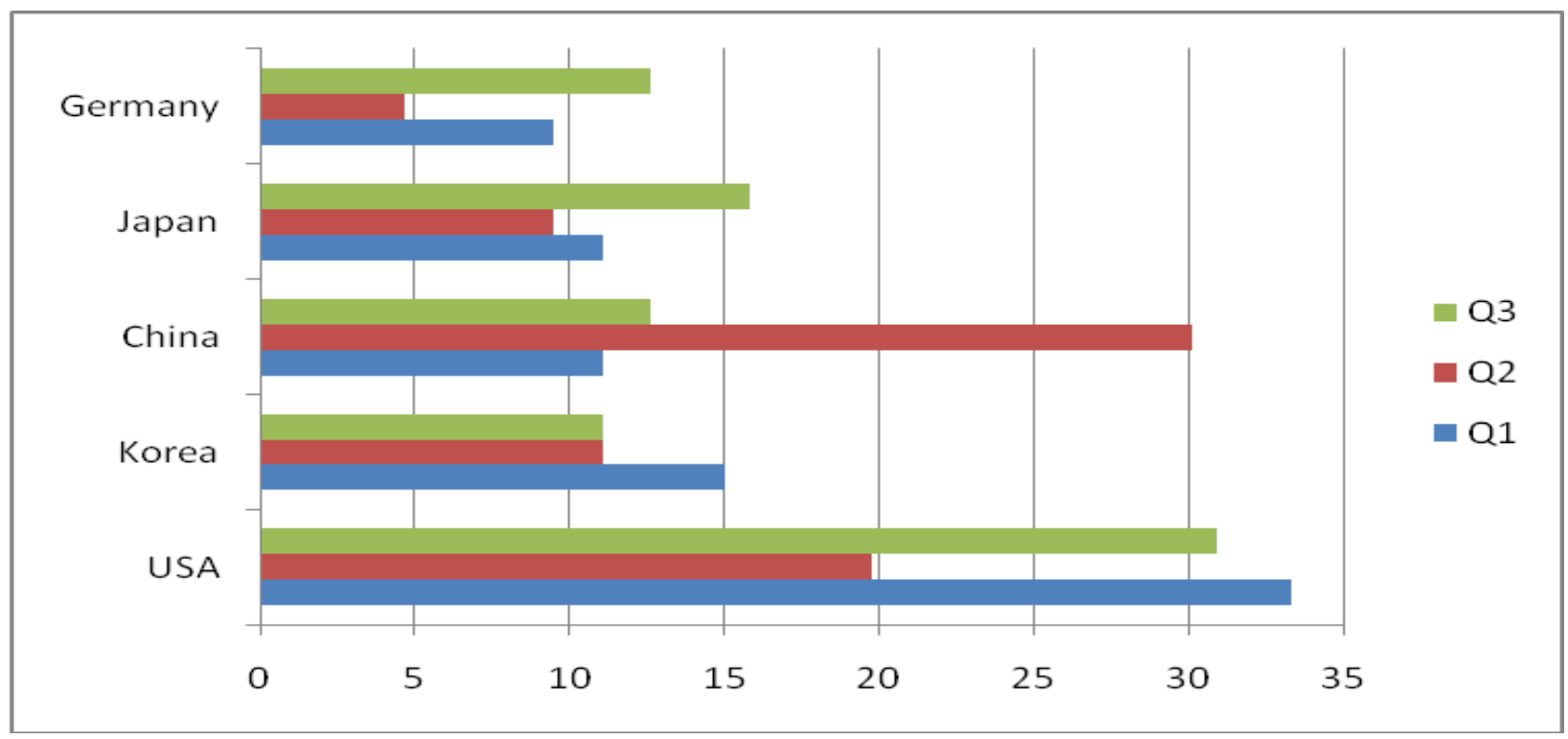

Source: own adaptation based on respondents' answers

As for purchase intention the results are as follows:

1. COO for the product they would like: USA leads by far, followed by Korea, Japan and China are quite similar and Germany is on the last place

2. COO of the product they would probably buy: China leads by far, with USA in the second place, Korea and Japan quite similar and Germany in the last place.

3. COM for the product they would buy assuming they do not know the COB: USA leads, with Japan in the second place, Germany and China are quite the same and Korea in the last place.

\section{CONCLUSIONS:}

I used SPSS to find the alpha- Cronbach coefficient which is 0.887 , that means the test is valid and reliable.

$\mathrm{H} 1$ : COO is important for the buying decision of the hybrid products considered

Only $14 \%$ of the respondents believe that COO is not important for the product they have bought, the remaining $84 \%$ assign some degree of importance to the $\mathrm{COO}$, therefore the first hypothesis is sustained.

$\mathrm{H} 2$ : the perceived $\mathrm{COO}$ is confusing for the hybrid products 
Figure 4: COB, COM, COD and "made in .." as predictors for COO

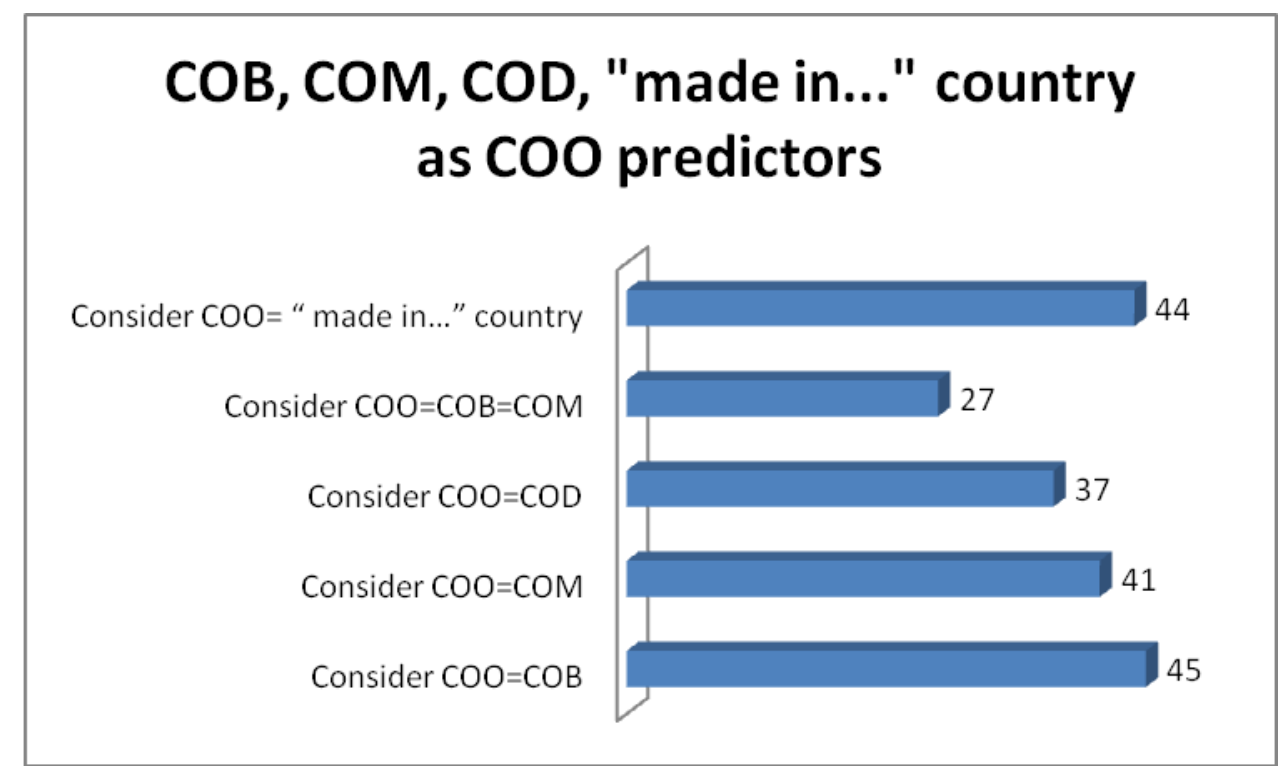

Source: own adaptation based on respondents' answers

As we can see the best predictors for $\mathrm{COO}$ in case of hybrid products are the $\mathrm{COB}$ ( which counts for $35.7 \%$ of the answers) and the "made in ..." country (which counts for $34.9 \%$ ), therefore about one third of the respondent were able to identify the $\mathrm{COO}$ of the product they bought, while almost the same do not care or do not know the COO. Therefore $\mathrm{H} 2$ is sustained.

H3: The correlation between the perceived $\mathrm{COO}$ and the perceived $\mathrm{COB}, \mathrm{COM}$, and COD are significant, positive and medium strong for the considered hybrid products

The correlations between the perceived $\mathrm{COO}$ and the perceived COB, COM, COD are significant, positive yet low, the best one is between $\mathrm{COO}$ and COM. Therefore H3 is partially sustained.

$\mathrm{H} 4$ : the $\mathrm{COO}$ for the considered hybrid products is different for the evaluation of the product and for the purchase intention

Although the $\mathrm{COO}$ of the hybrid products they prefer and would like to buy are developed countries like USA, Japan, Korea and Germany, for the purchase intention China is the expected COO. This might be explained by the low level of the income in Romania, so the consumers have to buy the products they can afford and offers the best value for the money and as many facilities as possible.

As expected identification of the proper $\mathrm{COO}$ for hybrid products is more demanding for consumers comparing to uni-national products. 


\section{References}

AHMED, S. A. and D'ASTOUS, A. (1993), Cross-National Evaluation of Made-in Concept UsingMultiple Cues, European Journal of Marketing, 1993, vol. 27, no. 7, s. 39-52

AHMED, S. A. and D'ASTOUS, A. (1995), Country-of-Origin and Brand Effects: A Multi-Dimensional and Multi-Attribute Study, Journal of International Consumer Marketing, 1996, Vol. 9, No. 2, s. 93-115

ANDERSON, W.T., CUNNINGHAM, W.H. (1972), Gauging foreign products promotion, Journal of Advertising Research, 1972, vol.2, s.29-34

BANNISTER, J.P., SAUNDERS, J.A. (1978), UK consumers' attitudes towards imports: the measurement of national stereotype image, European Journal of Marketing,1978, Vol. 12, No. 8, s.562-570.

BOURKE, A. (2000), A Model of the Determinants of International Trade in Higher Education, The Service Industries Journal, 2000, vol.20, no 1, s. 110-138

BOTSCHEN,G. and HEMETTSBERGER,A. (1998), Diagnosing means-end structures to determine the degree of potential marketing program standardization, Journal of Business Research, 1998,vol. 42, s.151-159

CHAO, P. (1993), Partitioning Country of Origin Effects: Consumer Evaluations of a Hybrid Product, Journal of International Business Studies,1993, Vol. 24, No. 2, s.291-306.

CHASIN, J. and JAFFE, E. (1979), Industrial buyer attitudes towards goods made in eastern Europe, Columbia Journal of World Business, 1979, Vol. 14(Summer), s. 74-81

CRAWFORD, J and LAMB, C. (1981), 'Source preferences for imported products, Journal of Purchasing and Materials Management,1981, Vol.17(Winter),s.28-33

DARLING, J. R. and KRAFT, F. B. (1977), A competitive profile of products and associated marketing practices of selected European and non-European countries, European Journal of Marketing, 1977, Vol. 11, No. 7, s. 11-23

D'ASTOUS, A. and AHMED, S.A. (1995), Multidimensional Country-of-Origin Effects on Product Evaluations: A Study in Morocco, International Journal of Commerce and Management, 1995,Vol. 5, No. 3,s. 32-45.

EHRNROOTH, H. and GRONROOS, C. (2013), The hybrid consumer: exploring hybrid consumption behaviour, Management Decision, 2013, Vol. 51, No. 9, s.1793 - 1820

ELLIOT, G. and CAMERON, R. (1994), Consumer Perception of Product Quality and the Country-ofOrigin Effect, Journal of International Marketing,1994, vol. 2, s. 49-62

EROGLU, S. A. and MACHLEIT, K.A. (1989), Effects of Individual and Product-Specific Variables on Utilising Country of Origin as a Product Quality Cue, International Marketing Review, 1989, vol. 6, No. 6, s. 27-52.

ETTENSON, R. and GARETH, G. (1991), Consumer perception of hybrid products, Journal of Consumer Marketing,1991, Vol. 8, No.4, s. $13-18$

GANDOLFO, A. and PADELLETTI,F. (1999), From direct to hybrid marketing: a new IBM go-to-market model, European Journal of Innovation Management, 1999, Vol. 2, No. 3, s.109-117

GHAZALI, M., OTHMAN,S.,YAHYA, A. and IBRAHIM, S. (2008), Products and Country of OriginEffects: The Malaysian Consumers' Perception, International Review of Business Research Papers, 2008, Vol. 4, No.2, March, s.91-102

GÜRHAN-CANLI,Z. and MAHESWARAN, D. (2000), Cultural variations in country of origin effects, Journal of Marketing Research, 2000, vol. 37, no. 3, s. 309-317

HAMIN, H. and ELLIOTT, G. (2005), A less-developed country perspective of consumer ethnocentrism and "country of origin" effects: Indonesian evidence, Asia pacific journal of marketing and logistics, 2005, vol. 18 , no.2, s.79-92 
HAMZAOUI, L. and MERUNKA, D. (2006), The impact of country of design and country of manufacture on consumer perceptions of bi-national products' quality: an empirical model based on the concept of fit, Journal of Consumer Marketing, 2006, vol. 23, no.3, s. 145-155

HAN, C.M. and TERPSTRA, V. (1988), Country-of-origin effects for uni-national and bi-national products, Journal of International Business Studies,vol.19,pp. 235-255.

HESTER, S. and YUEN, M. (1987), The Influence of Country of Origin on Consumer Attitude and Buying Behavior in the United States and Canada, Advances in Consumer Research,1987, Vol. 14, s. 538542

HUGSTAD, P. and DURR, M. (1986), A study of country of manufacturer impact on consumer perceptions, in N.I. Malhotra and J. Hawes (Eds.) Development in Marketing Science, Academy of Marketing Science, Coral Gables, 1986, Vol. 9, s.155-199.

INSCH, G. S. and McBRIDE, J. B. (1998), Decomposing the Country-of-Origin Construct: an Empirical Test of Country of Design, Country of Parts and Country of Assembly, Journal of International Consumer Marketing, 1998, Vol. 10, No.4, s. 69-91

INSCH, G. S., McBRIDE, J. B., (2004), The impact of country-of-origin cues on consumer perceptions of product quality: A binational test of the decomposed country-of-origin construct, Journal of Business Research, 2004, vol.57, no. 3, s. 256-265.

IYER, G. R., and KALITA J. K. (1997). The Impact of Country of Origin and Country of Manufacture Cues on Consumer Perceptions of Quality and Value. Journal of Global Marketing, 1997, vol.11, no. 1, s. 7-28

JAFFE, E.D. and NEBENZAHL, I. D. (2001), National Image and Competitive Advantage -The theory and practice of country-of-origin effect, Copenhagen Business School Press, Copenhagen

JAVALGI, R.G., CUTLER, B.D. and WINANS, W.A. (2001), At your service! Does country of origin research apply to services?, The Journal of Services Marketing, 2001, vol. 15, no. 6-7, s. 565- 582

JENES B., MALOTA E. (2009), Measuring country image - theory and practice, Retrieved from http://marketing-trends-congress.com/2009_cp/Materiali/Paper/Fr/Jenes_Malota.pdf

JOHANSSON, J.K. and NEBENZAHL, I.D.(1986),Multinational production: Effect on brand value, Journal of International Business Studies,1986, vol.17,s..101-126

KAYNAK, E., KUCUKEMIROGLU O., HYDER, A. S. (2000), Consumers' country-of-origin (COO) perceptions of imported products in a homogenous less-developed country, European Journal of Marketing, 2000, Vol. 34, no. 9-10, s. 1221-1241

KIM, S. and PYSARCHIK,D. (2000), Predicting purchase intentions for uni-national and bi-national products, International Journal of Retail \& Distribution Management,2000, Vol. 28, no. 6, s. 280 291

KLEIN, J. G., ETTENSON, R. and MORRIS, M. D. (1998), The Animosity Model of Foreign Product Purchase: An Empirical Test in the People's Republic of China, Journal of Marketing, 1998, vol.62, no. 1 , s. 89-100.

KUCUKEMIROGLU,O. (1999), Market segmentation by using consumer lifestyle dimensions and ethnocentrism: An empirical study, European Journal of Marketing, 1999, Vol. 33, no. 5-6, s.470 487

LAMPERT, I. S. and JAFFE, D. E. (1998), A dynamic approach to country-of-origin effect, European Journal of Marketing, 1998, Vol. 32, no. 1-2, s. 61-78

LIEFELD,J.and WALL, M., (1991), Impact of country-of-origin cues on consumer judgments inmulti-cue situations: a covariance analysis, Journal of the Academy of Marketing Science, 1991, vol.19, no.2, s.105-121. 
LIGHT, D., GAZDA, G. and BROWN, J., (1990), An examination of consumer evaluations of purebred and hybrid automobiles from selected countries, Proceedings of the Association for Global Bussiness, vol. November, s.143-152

LIM, K. and O'CASS, A.(2001), Consumer brand classifications:an assessment of culture-of- origin versus country-of-origin, Journal of product \& brand management, 2001, vol. 10, no. 2, s. 120-136

MENG J., NASCO S. A. and CLARK T. (2007), Measuring Country-of-Origin Effects in Caucasians,AfricanAmericans and Chinese Consumers for Products and Services, Journal of International Consumer Marketing,2007, Vol. 20, no. 2, s. 17-31.

NEBENZAHL, I.D.and JAFFE, E.D., (1997), Measuring the joint effect of brand and country image in consumer evaluation of global products, Journal of Marketing Practice: Applied Marketing Science, 1997, vol. 3, no. 3, s.190-207

NICOLESCU, L. (2011), Trends in the Country of Origin Effect theories: goods versus services, in: Proceedings of the International Conference Abordări moderne în managementul şi economia organizaţiei, Academy of Economic Studies Bucharest, Romania, 2011, November 24-25

OSGOOD, C. E. and TANNENBAUM, P. H. (1955), The principle of congruity in the prediction of attitude change, Psychological Review,1955, vol. 62, s. 42-55

PARAMESWARAN, R. and YAPRAK, A. (1987), A Cross-National Comparison of Consumer Research Measures, Journal of International Business Studies, 1987,vol.18 (Spring), s. 35-49

PECOTICH, A., Pressley, M. and ROTH, D. (1996). The impact of country of origin in the retail service context, Journal of Retailing and Consumer Services, 1996, Vol. 3, no. 4, s. 213-224

REIERSON, C.C. (1966), Are Foreign Products Seen as National Stereotypes?, Journal of Retailing, 1996, Vol. 42, s. 33-40

SHIMP, T. A. and SHARMA, S. (1987), Consumer ethnocentrism: Construction and Validation of the CETSCALE, Journal of Marketing Research, 1987, vol.24, no. 3, s. 280-289.

SCHOOLER, R.D. (1965), Product bias in the Central American common market, Journal of Marketing Research, 1965, Vol 2, no. 4, s. 394-397

SRIKATANYOO, N. and GNOTH, J. (2002), Country image and international tertiary education, Journal of Brand Management, 2002, Vol. 10, No. 2, s. 139-146

TAMAS, A. (2014), Advantages of study abroad from the students' perspective, Proceedings of the Proceedings of the 12th International Academic Conference, 2014, s. 1197-1215

TAN, S.-J. and LEONG, W.-Y. (1999), Warranty Strategy: A Solution to Hybrid Product Woes?, International Marketing Review, 1999, vol.16, no. 1, s.40-64.

THAKOR, M. V. and KOHLI, C. S. (1996), Brand Origin: Conceptualization and Review, Journal of Consumer Marketing, 1996, Vol. 13, no. 3, s. 27-42.

THORELLI, H.B., LIM, J.S. and YE, J., (1989), Relative Importance of Country of Origin, Warranty and Retail Store Image on Product Evaluations, International Marketing Review, 1989, Vol. 6, no. 1, s. 3546.

ULGADO,F.M. and LEE, M. (1993), Consumer evaluation of bi-national products in the global market, Journal of International Marketing, 1993, Vol.1, no. 1, s. 5-22

USUNIER, J.C. (2002), Le pays d'origine du bien influence-t-il encore les évaluations des consommateurs ?, Revue Française de Marketing, 2002, no. 189-190, s. 49-65.

VEALE, R. and CHALLEN, R. (2010), Is it what you know or where you are from? Revealing the influence of a country of birth and country of training on consumer expectations of service quality, Proceedings of the International Service Research Conference(AMA SERVSIG), June, Porto, Portugal 
WALL M., LIEFELD J. and HESLOP L. A. (1991), Impact of country-of-origin cues on consumer judgments in multi-cue situations: a covariance analysis, Journal of the Academy of Marketing Science, 1991, vol.19, no.2, s. $105-113$

ZHANG, Y. (1997), Country-of-origin effect: The moderating function of individual difference in information processing, International Marketing Review, 1997, Vol 14, no. 4, s. 266-287 